\title{
THE DUTIES OF THE SUPERVISING PRINCIPAL
}

W. C. REAVIS

Superintendent of Schools, Alton, Illinois

In a recent article on "The Work of Elementary-School Principals" the fact was pointed out that principals are inclined to overemphasize certain aspects of their work and to neglect others. This state of affairs is not to be wondered at when we consider the neglect that this important field of educational work has suffered in our educational literature, in university instruction, and in the narrow and often one-sided interpretation given to the principal's duties by superintendents and boards of education in their rules and regulations issued for the guidance of the principal.

The purpose of this article is to present the duties of the supervising principal in their entirety, rather than to consider the merits or demerits of the different types of principal; and to maintain that it is more important to the school for the principal to view his work clearly from many angles and properly to discharge all of his duties than to hold a warped conception of his functions and to excel in those phases of work at the neglect of other phases.

The principal should be regarded as the responsible head of his school, and as such he is invested with duties managerial, professional, and social in character. It is necessary that the principal have a full, clear conception of the many duties that are grouped under each of these divisions in order to administer his school properly and not to interfere with the co-ordination of functions within the school system.

${ }^{x}$ GRAY, W. S., The Work of Elementary-School Principals, Elementary School Fournal, 19; Sept., 1918, 36-40. 


\section{MANAGERIAL DUTIES}

The managerial duties of the principal are comparatively simple or complex according to the size of his school, the arrangements of the building, the equipment of the building, the character of the community, the co-operation of parents, the assistance rendered by teachers, the administrative demands and requirements of the school system, and the quality and amount of clerical help allowed. As most of these problems can be overcome in due time by good executive ability on the part of the principal, it is fair to assume that permanent resistance to success as the manager of the school would be prima facie evidence of either executive weakness or the lack of a proper conception of managerial duties.

Many principals maintain that much of their time is consumed with managerial duties alone, and that no time is left for the other duties which they recognize as important, but which are neglected for want of time. The significance of this reasoning can be tested by analyzing such duties and by ascertaining the methods employed in meeting them.

In every school there are certain daily managerial duties that must receive the attention of the principal, and the rapidity and ease with which he discharges them measure his efficiency as a manager of a school plant. (I) The school plant should be inspected daily before the opening of school to see that it is in proper physical condition for school work. (2) New pupils presenting themselves for admission must be classified and assigned to rooms. (3) Cases of tardiness, truancy, and applications for excuses referred by teachers should receive prompt attention. (4) The mail must be examined, and that requiring attention must be answered. (5) Visitors or callers should be received and given attention.

There are many other managerial duties that should be performed chiefly outside of school time in case no clerical assistants are allowed to whom such duties may be delegated. 
The proper organization of the school with a clear differentiation of responsibilities among the different members and a definite program for attending to such duties as ordering supplies and repairs, keeping records up to date, making reports promptly, making the pay-roll, attending to cases of discipline, handling the problems arising from inclement weather, giving fire drills, and excusing from school not only enables the principal to accomplish more work, but also contributes to the general order and efficiency of the school. Now it is evident that, without good system and the knack of managing, a principal might give his entire school time to managerial duties of the character mentioned, accomplish practically nothing in the other phases of his work, and yet be less efficient in managerial work than the principal who distributes his time systematically to all the duties connected with his functions in the school.

In schools where clerical help is not furnished, principals sometimes follow the practice of distributing many of their routine managerial duties among the teachers. While this plan does allow the principal time for other duties, the practice on the whole is bad and should be discouraged, because it is usually done at the expense of time which belongs to instruction.

\section{PROFESSIONAL DUTIES}

The professional qualifications of principals do not measure up ordinarily to their managerial qualifications. Yet it is in this field of duties that the greatest skill is required. The trained supervising principal should spend a large portion of his time in studying the character of instruction in his school, in interpreting the results of instruction, and in so co-ordinating the work of his teachers that real team-work is secured. In order to accomplish this it is necessary for him to spend much of his time in the classrooms, and these visits to be valuable must not be random in character, but must be planned 
with a definite purpose in view. Random visits to classrooms to see whatever lessons chance affords will not necessarily reveal the facts the principal needs to know; but visits planned in accordance with the programs of the teachers so that the work in a given subject of the curriculum throughout the school or lessons by the same teacher on consecutive days can be observed will furnish data that will be valuable in determining the relative strength and weakness of teachers and in co-ordinating the sequential steps in the development of subject matter of the subject of instruction under observation in the different classrooms.

But the principal must not rely altogether upon qualitative judgments, however systematic and well planned his methods of classroom observation may be. Qualitative judgments must be supplemented with the results of scientific tests and careful educational studies. The principal should familiarize his teachers with the various educational tests and should habituate his pupils to respond naturally to such exercises in order that the results secured will reveal the true status of work in the various classrooms of his school.

The principal who makes use of both the qualitative and quantitative data will be able to approach his problems with a degree of expertness that will arouse confidence in those with whom he works. He will be able to classify pupils more accurately; to promote classes more wisely; to make programs more scientifically; to direct the work of apprentice, substitute, or regular teachers more effectively; to rate his teachers more justly; and to confer with teachers either in general or in group meetings with the assurance that definite benefits will result from the discussions.

It is not the professional duty of the principal to formulate the educational policy of his school, but to interpret for the teachers of his school the policies formulated by the superintendent and special supervisors, and to direct the teachers' 
efforts along the lines that will produce the best results for the children of the school. The principal thus becomes an intermediary between the superintendent and special supervisors on the one hand and the teachers, pupils, and school patrons on the other. Upon him rests the professional responsibility of executing many of the educational ideals of the superintendent, and in this the principal's success will be determined largely by the thoroughness and professional character of his knowledge of his own school conditions.

\section{SOCIAL DUTIES}

In addition to the managerial and professional duties of the principal there is a round of duties, not prescribed in the rules and regulations of the board of education, which may receive considerable attention or remain undone without arousing much protest from anyone. These duties are essentially social in character, and in the opinion of many administrators are just as imperative to the welfare of the school as are many of the duties formally prescribed. They are vitally related to the development of esprit de corps, school spirit, and community spirit.

There seems to be a growing tendency among principals to give more attention to a wider range of social duties than formerly. For example, many principals now spend considerable time in securing the co-operation of parents' associations, in encouraging the wider use of the school plant by the community, in making of the school a community center, in directing the organization of play activities on the school grounds, and in developing neighborhood co-operation in the necessary civic movements of the school district. The proper encouragement and direction of such out-of-school activities require much time and energy on the part of a principal, but the results generally obtained are so intimately related to the success of the school that a principal with a broad conception of his work 
would consider himself derelict if he failed to perform these duties conscientiously and as efficiently as possible.

If the supervising principal is fully informed regarding the range and character of duties that confront him, the task that remains is a crucial test of fitness. He must be able so to apportion his time that he will not be misled by his own interests. This requires a proper evaluation of every duty in the light of actual school needs; and the principal who plans his program on this basis will without doubt render a greater service to his school than will the type of principal who devotes his time only to certain aspects of his work. 